\title{
Nephritic Syndrome
}

National Cancer Institute

\section{Source}

National Cancer Institute. Nephritic Syndrome. NCI Thesaurus. Code C123199.

A syndrome characterized by hematuria with dysmorphic red blood cells, red blood cell casts, and proteinuria; systemic manifestations may be present, including hypertension, edema, oliguria. 